\title{
Beyond Informality: Effectiveness of a New Actor For Representing Call Centre
}

\section{Workers in Turkey}

\section{Abstract}

This paper explores the organisational dynamics of the 'Association of Call Centre Workers' and aims to discover the effectiveness and sustainability of it as a new actor for representing the interests of call centre workers in Turkey. While traditional trade unions have fundamental problems such as efficacy and representation of various worker groups in changing workplaces, in the Turkish context they have additional difficulties based on structural and legal constraints. Call centre workers seldom utilize the formal representation channels because of these and some other individual reasons such as a lack of information about their rights and labour movements. Moving from the importance of analysing the informal worker organisational dynamics in the case of a new trade union for call centre workers, the emphasis of the research is on the ability of the association to develop a form of resistance and representation for the previously unrepresented.

Keywords: call centres, worker resistance, worker representation, non-trade union worker organisations.

\section{Introduction}

Recent studies of industrial relations and labour process issues have made assumptions about the weakening of organised labour, insignificance of collective action and disappearance of conflict in contemporary workplaces. However, social and economic relations between capital and labour are still a form of 'structured antagonism' (Edwards 1990), and it is inevitable that modern workplaces are still a contested terrain in which managers and workers continually renegotiate the terms of employment based on the power resources of the two sides. In this context, worker perceptions of working conditions develop 
worker desire for a collective voice and representation to enhance their bargaining power visa-vis the employer (Bryson and Freeman, 2013: 1-2).

The traditional actors for worker voice and representation are trade unions with collective bargaining. Unions have the established channels for representation whereas collective bargaining is a constructive process aimed at promoting interests and resolving conflict (Tapia and Turner, 2013: 603). However, in recent decades there have been numerous changes that have influence on the traditional actors and institutions in industrial relations. Union efficacy and inclusive collective bargaining system have been declining as a result of neo-liberal economic policies and changes such as deregulation, flexibility, and individualisation in working life. In addition to such external challenges, there are internal factors like lack of employee trust in unions that forms member commitment. These circumstances have been converting the unions into a consultative force in many countries (Tapia, 2013: 667).

Union decline refers to many changes that affect the unions both quantitatively and qualitatively. While unions are dealing with difficulties about membership, effectiveness, bargaining power and political influence (Findlay and Warhurst,2011: 115) in many advanced economies, they have more fundamental problems in developing countries. The changing structure of production regimes, increasing importance of service-producing industries, increase in subcontracting, high unemployment rates and negative attitudes of employers about unions, legal and also political restrictions are among the problems that determine union decline in these countries. It is a fact that unionisation rates are declining in most parts of the world and although the majority of employees are not covered by collective bargaining in advanced economies (Tapia, 2013: 667), the decline of unionisation rates is not as acute as in developing countries. 
As traditional trade unions mobilise the interests of labour and negotiate terms of work within the labour process (Ackers et al. , 1996: 1), the decline in the power of trade unions has led particularly to some considerable gaps in representing the interests of workers and the expression of voice. Contemporary trade unionism is challenged not only in representing the interests of workers (Jenkins, 2013: 623) but also in mobilising them to act collectively. If there are no such traditional channels, workers may require a more active mobilisation to represent their interests (Tapia and Turner, 2013:603).

The first answer to the question of how the representation gap mentioned above might be filled is the revitalisation of the unions. The main focus of revitalisation debates in advanced economies is about the difficult adaptation of unions to the changes in society and economy, as well as the idea that existing unions cannot meet the interests of a changing workforce. The second identifies a role for new and alternative actors for worker representation. (Heery et al., 2004: 1-3).

There is also another outlook focusing on a 'hybrid' approach (Tapia, 2013: 668). This approach is based on the idea of combining trade union activities with new actors and actions. Some scholars are supporting the idea of collaborative network of these two organisational forms to make the labour movement more effective (Heckscher and Carre, 2006: 617).

Given the significance of the current debates about alternative labour organisations in the global context, this paper explores new developments in the organisation and representation of call centre workers' interests in Turkey. As in other developing economies, there has been a tendency for such workers to be dismissed by traditional trade unions. As labour relations are influenced by the political and economic structure of the country they appear in, there are considerable inter-country differences regarding labour market conditions and structure of industrial relations. In other words, it is better to grasp developed 
and developing countries as analytical categories as well as to note the differences within each category. There is a process of weakening of traditional industrial relations institutions because of the radical labour market changes in Asian countries leading to new models of industrial relations (Sen and Lee, 2015) similar to the Turkish case, the Turkish industrial relations system is distinguished from other developing countries in certain dimensions ${ }^{1}$. Typical of the developing countries such as India, Vietnam, Taiwan, and South Africa, the collective action tradition is stronger than in Turkey, and particularly in South Asia, worker organisations for informal and unorganised workers have been effective since the 1970s (Sen and Lee, 2015:38). Demonstrating the issues in developing countries, Jenkins (2013) focuses on a recent grass-root organisation for garment workers and their organising experience as a non-union worker movement in India and Cox (2015) discusses the case of unofficial worker representation and the appearance of wildcat strikes in Vietnam. Webster (2015) also emphasizes the South African context and rising collective actions after the 1990s.

However in Turkey, trade unions and worker organisations have limited power in labour relations because of various causes such as a lack of collective consciousness and the unsettled culture of democracy. Social and democratic rights have been given by following advanced economies without forming the required institutional and social structure. After the last military coup in 1980, unemployment increased because of the economic crisis; in addition, outsourcing and atypical employment strategies made organising difficult for trade unions (Tokol, 2012). Traditional trade unions have always had difficulties in becoming

\footnotetext{
${ }^{1}$ The developing countries cited here have similarities with Turkey about their position in international division of labour, their labour-intensive production strategies, vulnerable and unorganised worker groups in the global economy. However, their collective action potential is relatively different than the Turkish case.
} 
effective actors, particularly after the law change in 1983 that included bans and antidemocratic regulations for collective organisations.

In these circumstances, social, economic and legal constraints, as well as deunionisation policies of the government, impact trade unions and their effectiveness, and it is mostly not possible themto constitute 'countermovements' (Tapia et. al, 2014) against the violation of worker rights. However, as Hyman (2015) indicates for the future of industrial relations in developing countries, a 'new-counter movement' is shaped from below to fill the gap and to fight for the rights of the excluded from the industrial relations system. This tendency is similar in Turkey just as in other developing countries and advanced economies although it has its own circumstances and limitations.

After the transformation of global production regimes and the rising importance of the service sector, traditional trade unions have additional problems with organising workers in new and decentralized workplaces such as call centres. When organising strategies in call centres are considered, any type of trade union membership scarcely exist, which is not only related to the tradition of Turkish industrial relations but also to the increasing pressure on becoming organised. It is hard to reach unions or effective representation channels for call centre workers and for this reason, they have been organised under a non-union worker organisation form since 2006: The Association of Call Centre Workers (ACCW). The Association has developed some novel ways of taking action. However, more recently, a change in the Turkish Trade Union Law has allowed call centre workers to be unionised. After this change in May 2013, the founders of the ACCW sought to build a new trade union called the "Progressive Communication and Call Centre Workers Union" and interestingly, they have maintained the existence of a more informal organisation. 
The paper starts with the discussion in Section 2 about the worker representation gap and how this can be filled by different organisational structures. Section 3 explains the methodology of the study, and the subsequent section outlines the research findings by analysing the case study. Finally, Section 5 covers the discussion about the significant structural differences between other alternative organisations and the Association of Call Centre Workers, and specific characteristics of the Association in the Turkish context, as well as recent developments and future prospects.

\section{Worker Representation Gap and New Actors in Industrial Relations System}

As actors for mobilising the workers, traditional unions are restricted by legal regulations that determine their members and their actions. Their strategic orientation prevent them from organising some of the most exploited groups of workers. Some industries and sectors are abandoned by unions in the case of legal arrangements (Sullivan, 2010). In this perspective, some excluded occupational categories and other groups -immigrants, ethnic minorities and subcontract workers - who do not have access to the formal industrial relations actors and are outside of the collective bargaining coverage, have the potential to mobilise through informal organisations.

When thinking about non-union, informal representative institutions, one type is created by employers in response to unionism. They primarily tend to promote information sharing and consultation but not bargaining. These kinds of management-driven forms of participation often concentrate on individuals rather than collective voice (Freeman et al, 2007:5). Another type is standing out against these anti-union managerial strategies. It could be observed for some alternative organisations and 'new' actors such as community-based labour organisations or worker centres, which might fill the representation gap. These types of non-traditional forms of worker organisations provide workers with a range of 
opportunities for expressing their "collective voice" as well as for taking coordinated action (Fine, 2005b: 420).

Nevertheless, there is a widespread tendency that excludes these types of organising practices, which reflects a union-centric character in mainstream industrial relations studies. Academic research about labour renewal remains union oriented (Sullivan, 2010). “Organising the unorganised" primarily means a revitalisation attempt of trade unions (Heery and Adler, 2004). This focus is quite problematic because of the strategic value of these organisations and their potential to increase the voice of workers.

There are some similarities and differences in organisational forms between different types of new actors in different countries. For example, community unions are communitybased organisations that focus on issues about work and wages in their communities. Some of them are new, like worker centres; others are existing organisations that adopt new strategies like unions (Fine, 2005a: 154). Workers centres are examples of this type, as they are community-based, mediating institutions that provide support to communities of lowwage workers and represent their interests. They are found in the US and Canada and have members who are mostly recent immigrant workers (Suzuki, 2008: 496). Some of them are based in specific industries, while some worker centres have been organised by ethnic or faith-based organisations. They are place-based organisations instead of worksite-based unions. They might act like social movement organisations, labour market institutions or a new organisational form that is a combination of these two types (Fine, 2005b: 420-427). Worker centres are primarily non-bureaucratic, grassroots with informal membership structures and small budgets (Fine et al.,2008: 30). They are claimed to share some similar characteristics such as the type of workers organised, organisational forms and membership structures. They have several missions, including service delivery, advocacy and organising. 
There is another type that can be included into community-based organisations called 'Industrial Areas Foundations' (IAF) in the US. These are also geographic-based organisations that concentrate on bringing social change through the use of public advocacy and collective action. Their organising model is based on empowering workers through campaigns and mobilisation (Tapia, 2013; Osterman, 2006). Community organisations are also called nonbargaining actors that represent select interests of particular workers (Givan, 2007: 830).

Characteristics and the 'who', 'what', and 'how' of representation (Hyman, 1997) depend on the conditions of the labour market or the structure of the industrial relations system of the country in which it exists. For example worker centres organise mostly immigrant workers or they have relations with faith-based organisations. This situation is directly related with the country they are in. The US or Canada have large populations of immigrants and worker centres in these countries are not only effective in solving workplacebased problems of the workers, but they also reach them in the areas in which they live and organise them according to improve their social conditions. Consequently different conditions create different solutions for filling the gap that unions leave for representing the workers' interests.

Another point under discussion is the potential of non-union labour organisations to form a union in the future. Some of the scholars call them 'quasi-unions' (Hecksher and Carre, 2006), 'pre-unions' (Jenkins, 2013) or proto-unions (Sullivan, 2010). For example, Heckscher and Carre discussed that quasi-unions have not come close to growing into a new model of unionism as they are far from having enough power to make changes (2006: 613). In another study, Jenkins (2013), analysed a grass-roots organisation as a case of local activism by female garment workers in India. She employed the pre-union concept for describing the organisation model, evaluating it from a social movement to a union. 
The questions here are less what to call them, but more "how and why they make a difference' (Michelson et al. 2009) and 'are they capable of representing the workers who do not have a voice across the employer' and additionally 'which forms of representation are most effective in advancing the interests of workers?' (Heery, 2010). This study explores one of these emergent forms of organisations and the debates amongst scholars and activists as to whether they are a substitute or complement to formal trade unions according to the industrial relations system of the particular countries. It stays close to another tendency in academic writings, which suggests that it is not necessary that non-trade union worker organisations should eventually become a trade union Although there are similarities and differences between trade unions and the other forms, each type of organisation has its own characteristics and a unique role in industrial relations system (Tapia, 2013: 668).

It is also important whether non-trade union worker organisations represent a path for the future development of a representation structure. This calls the effectiveness problem of these organisations to mind. Although it depends on where and in which conditions they exist, they demonstrate some ability to operate in areas where unions are absent and to provide forms of representation. However, very few have managed to break through from the early stage to more sustained organisations and they remain very far from attaining enough power to make major changes in employer policies and practices (Hecksher and Carre, 2006: 612-613).

These new actors have also been criticised by the formal trade union movement for their limited geographical reach. Although their organisational forms are unclear, there are many cases in which they have been more successful in reaching vulnerable workers. However, for some scholars, the key issue about sustainable success in the representation of 
labour's interests is a combination -which is mentioned as a hybrid structure- of social movement style mobilisation and unions (Jenkins, 2013: 627).

The main objectives in this point to explore the applicability of the new actors in the industrial relations framework to the Turkish context in the case of the Association of Call Centre Workers and the differences between the other non-union worker organisation models and the Association. These will be discussed after the presentation of the research methodology and the findings.

\section{Methodology}

This research examines the effectiveness and sustainability of a non-trade union worker organisation in the case of Association of Call Centre Workers in Turkey using focus group and semi-structured interviews with the founders and the members of the Association in a longitudinal study since 2010. The author has also been observing the regular meetings of the Association. The emphasis of the research is on their ability to develop a form of resistance and representation for the previously unrepresented. The main purpose of the study is to analyse the sustainability of the Association in cooperation with a new trade union for call centre workers.

The "Association of Call Centre Workers", the first and only informal organisation to organise call centre workers in Turkey, has been chosen as the case study, and the organisation processes as well as organisational structure have been analysed. During this process, the objective was to examine whether the association is a concrete example for the resistance mechanisms of call centre workers and to reveal its potential to represent the interests of workers. The Association was closely examined in many aspects ranging from its organising activities to its plans for the future. The author has also been observing the 
foundation process of the 'Progressive Communication and Call Centre Workers' Union' and contacted the founders about the first stages and struggles during the process.

The first focus group interviews were completed in two stages in May and July 2010. In the first stage of the fieldwork, seven people, three of whom were the founders of the Association, three of whom were members and one of whom was a non-member call centre employee, were interviewed. They had working experience between 3 months to 3 years in call centres. All of the participants (including the founders) had a background as a call centre worker in the banking sector. Accessing the founders was difficult because of the secrecy about the association and because there was no information about them on the website at the beginning. The interviews were recorded with the approval of the interviewees. They were held in the central office of the association in İstanbul. At this stage, the purpose was to discover the structure and organising activities of the Association. During the focus group interviews, the interviewees were asked questions concerning their age, educational level and how they heard about the Association as well as questions about their personal career plans, the place of the call centre in these plans and the working conditions. Their relationship with the association and the level of their membership were also among other discussion topics.

The second group interviews were conducted with the members and focus groups with the founders of the association between September 2012 and March 2013. Twelve members and six founders were interviewed with semi-structured and focus group interviews. These members were selected from the call centres with the help of information obtained from the founders after the focus groups, and they have problems and violations of rights. The interviewees were between 23-35 years old, and nine (of the twelve members) 
were undergraduate ${ }^{2}$ students. They had work experience of between 1 month and 5 years. Eight of the interviewees were working in in-house call centres, and the other four were working in outsourced call centres where the working conditions are reportedly harder. The interviews again occurred in Istanbul, and during this process, the author observed the meetings of the Association within non-participant observation. In the course of nonparticipant observations, the author did not intervene in the meetings at all but merely took notes without recording. The call centre workers who were not members of the Association attended the meetings, and after that, some of them became members.

A total of 25 interviews were undertaken through focus groups and semi-structured interviews during the longitudinal research process. It should be noted that the reason for not interviewing more people is that after a certain period, the answers given to the questions, and accordingly the data gathered became repetitive. Therefore, it was thought that 25 people would be sufficient to analyse the data in a reliable way. The interviews took approximately one and a half hours. All of the interviews were recorded and then transcribed by the author. In addition, the observation notes taken in the field were also employed in analysing the data.

\section{Research Findings}

Why an Association?

\footnotetext{
${ }^{2}$ Ofthe call centre workers in Turkey, $11 \%$ are in the category of undergraduate students and $71.2 \%$ of all workers are between 21-29 years old (www.cagrimerkezleridernegi.org). Although it is hard to clarify the exact member distrubution according to age and education because of an unsteady membership structure, most of the members are undergraduate students, and the interviewees represent the typical member profile.
} 
In the focus group interviews with the founders, the interviewees were asked why they had preferred to found an association rather than a trade union. Each participant had a different answer to this question. They stated that no one objected to being a trade union and they all emphasized that there are different ways to be an effective organisation.

"We wanted to found a really effective organisation. If you want to keep people together, you have to serve them effectively. The most legal form of this effectiveness is a trade union... We looked for a form. It was easy to have a trade union. However, if we cannot overcome the threshold, we cannot have collective bargaining. When we have no collective bargaining, we have de facto no difference from an association. It was easier for us to get organised in this way instead of a trade union that has a status but fails to enjoy its rights resulting from this status."(Ekin, founder)

The threshold mentioned in the statement above refers to the number of workers that a trade union in a specific branch of work has to have in order to sign collective bargaining. Although the threshold has been lowered from $10 \%$ to $3 \%$ of the workers in the branch of work with the new Trade Union Law, it is still maintained.

The interesting point here is the comment made by the founders in the focus group interview in September 2012: "Because the threshold remains the same, it is still meaningless for us to be a trade union. Being a trade union does still not enable us to sign collective bargaining. Since a trade union that is unable to sign a collective bargaining does not make any sense at all, we preferred to found an association." (Mehmet, founder) However, despite this opinion, they chose to turn into a trade union a short time after the above mentioned law was passed.

"We do not say we are not going to be a trade union or we are necessarily going to be a trade union. The point is to have an effective organisation. We are doing this legally and in 
a way that fits our internal functioning. You need to be organised first if you want to organise people effectively..."(Ekin, founder)

Being an effective organisation is undoubtedly related to that organisation's capacity to organise people. In this case, the organising activities have been accelerated because of the flexibility of acting informally. Ekin ${ }^{3}$ makes the following comment on the relations with trade unions and how the organisation fills the representation gap:

"The decline of trade unions will perhaps help such labour movements to fill the gap. But, will this make them a trend? I am not so sure of that. As a matter of fact, the decline of trade union movement means a total decline in labour movement. It means that the perception of labour movement changes negatively. You fill a gap. While doing this, you can act more flexibly. Unlike trade unions, you do not have legal restrictions. The main problem is that the labour movement is losing power in general."

Based on the founders' statements, it is possible to say that initially there was no clear preference about being an association or trade union and founding an association was preferred to founding a trade union only due to legal restrictions. However, the founders all admit that once they are informally organised, it is easier and more effective to become organised in this way.

\section{The Association of Call Centre Workers}

In Turkey, collective organising practices among white-collar workers are quite rare, and they are not regarded as workers become organised in trade unions ${ }^{4}$. That is why it is

\footnotetext{
${ }^{3}$ The names in this paper used for the founders and the members of the association are pseudonyms.

${ }^{4}$ The Plaza Action Platform, which organises white collar workers, could be given as an example of collective organising practices. Different from an association or a trade union, this Platform acts as an informal organisation and defines itself more like a solidarity network of white-collar workers. The Platform, one of whose
} 
necessary to mention the significant differences between Turkey and Western countries in terms of formal organising opportunities despite their similarities in terms of working conditions of call centres.

The Association of Call Centre Workers was founded in 2006 as a web site under the name of 'www.gercegecagrimerkezi.org'. At this first stage, it looked like a forum where members interacted and looked for support for their problems that they shared online rather than like a real association. In the first years of its foundation, the website whose name is literally translated into English as "call for truth" was no different from a standard forum where people shared legal updates and complaints about, injustices and negative things that employees encountered as well as meetings and protests organised by the association.

, a 'ghost' organisation model was employed, as there were highly intense control and surveillance mechanisms in the call centres, employees feared being fired and employers had a negative attitude towards such organisations. Organising activities were conducted in great secrecy. During this process, the ghost logo became the symbol of first the web site and then, the association. The secrecy was so strong that there was no information about the founders of the web site. However, after a while, the number of workers accessing the website turned outto be limited, and it became necessary to change to a more unambiguous system.

The inadequacy of the ghost organisation to organise employees and raise a voice to improve the working conditions paved the way for an association. In this respect, the efforts gained a more formal structure, and in 2008, the "Association of Call Centre Workers" was founded. The great majority of the founders had already worked for a call centre, and they knew the working conditions and were generally left wing. The founders' commitment to the

slogans is "Turnstiles separate but open spaces unite", also collaborates with the "Association of Call Centre Workers". 
association was initially based on volunteerism. Currently, most of them work in other sectors, but they take part in the organising activities of the Association on a regular basis.

The Association conducts its organising activities by first evaluating the e-mails of the call centre workers who report violations of their rights in the workplace and then, by being recognized in the workplace concerned. Next, they organise their most specific collective action, which is named 'call attack'. In these calls, the respondents are told that they are aware of the poor working conditions and problems in their workplaces and that they are not alone'. The employees are invited to act collectively and get organised. In addition to the call attack, they also distribute notices outside the workplace and talk to the workers one by one and organise them in this way.

The number of the members of the Association may change depending on the time and success of organising activities. The number of members increases when an injustice is solved in a workplace and advocacy is provided to the workers. However, after the problem is totally solved and there is legal success regarding the violation, the members may stop maintaining contact with the Association. It is a fact that people may become members not for collective but for individual reasons, which constitutes a problem for the Association. If a call centre worker gets in touch just for individual reasons, s/he may not contact again when his/her problem regarding the violation of rights is solved or mitigated. This situation, without any doubt, leads to ambiguities about the future of the Association and the sustainability of its activities.

It is a promising development for organising activities that the Association has gained media recognition in recent years. Several news articles about the actions of the Association to claim workers' rights have been published in the national papers, which has visibly contributed to the number of members. 


\section{Collective Actions and Activities}

\section{Organising}

The most effective organising implementations that the Association has been using since the very first day are the call attacks mentioned above. These actions might be easily accepted as literally voice mechanisms of the workers. Call attacks are organised on a prescheduled day as the founders and members get together to call the related call centres. The workers of the call centre where there are poor working conditions or there is a violation of rights are thus encouraged to become organised, and they are assured that they are not alone and there is an association from which they can get advocacy. After the call attack, many workers do want to become members, and in this way, a speedy organising potential is ensured.

The Association has had many successes through call attacks. One example is the action directed at the call centre of a private bank. In the workplace concerned, the call centre workers are forced to make sales as they are standing, and they are not allowed to sit down until the required sales quota is reached. An employee who was subject to this pressure contacted the association, talked about the conditions and asked for help. Upon this, the founders of the Association organised a call attack to the call centre of the bank with a group of members. After the employer listened to the call attack, the practice mentioned above was stopped.

One of the interviewees works for the bank mentioned above and reports what happened as follows:

"Tele-sale on foot... They take away your chairs. Unless you reach the sales target, you cannot sit down for hours. A call attack was organised to put an end to this practice and the company acquiesced. It was in this way that the employees heard about the association. 
Regarding this issue, another thing happened in the outbound sales department. One of the girls fainted while making sales. This once happened to me, too. I was not allowed to take a break without making sales. I was always on my feet. It was terrible..." (Esra, member) Apart from call attacks, the call centre employees who are members can post Association stickers as well as more general stickers about workers' rights in their workplaces to raise awareness among their colleagues. Moreover, the founders and workers distribute these stickers or periodical leaflets in different workplaces; they establish contact with the employees in person and thus, conduct organising activities. At this point, it should be noted that this movement, which started as a website but then turned into an association, worked secretly in its first years, but the achievements it has had and the strong support it has received have encouraged the members of the Association and workers to show themselves without hesitation. Thus, currently, the founders can have interviews with national newspapers, deliver speeches on the radio, influence public opinion about the negative things in a given call centre and help people to become organised.

As regards organising, the founders have recently paid a visit to some call centres in Anatolia, learned about the problems the workers encounter there and updated them about the association.

Concerning this issue, Mehmet, one of the founders stated as follows:

"The source of our power is human. We need to organise people. We need to give them something good. We need to fulfil their social needs. They need to learn their rights, how to be together. They need to feel that they are valuable. They need to understand that their problems are common. They need to ask for better working conditions...."

However, the decentralized structure of the call centres in Turkey makes organising difficult. Referring to the ghost structure of the association at the very beginning, even Ekin 
has indicated that now the workers are also like ghosts and who answers the call is ambiguous. She has added that such a scattered structure has a negative impact on organising.

Another observation that the author made during the meetings of the Association is that the founders seek ways to reach all workplaces in addition to the problematic ones. Regarding this issue, they have mentioned to put in charge a workplace representatives of the Association in specific call centres as a way to inform workers about the association and ensure organising. Organising people through the workplace representative is the key to organising workers at work. However, for the time being, there is no concrete development in regards to this.

\section{Advocacy-Providing Advice}

The Association helps the call centre workers who have problems through lawyers who volunteer to work for it. These lawyers provide legal information to the employees and help them present a case when required.

An example of this was experienced at the end of 2012. There was an unlawful development in an outsource call centre working for the biggest mobile phone operator of Turkey. The association started a legal fight against this illegality, which ended up as the most striking success. The company is one of the oldest call centres in Turkey, managing the call centre operations of many public institutions including ministries in addition to the mobile phone operator in question. A worker who left their job noticed that although he had been working on full-time basis, his/her insurance premiums were paid on part-time basis. Then, he contacted the Association. Once the Association shared this on the website, it was detected that the same case was valid for many other employees, too. Upon this, the Association contacted the employer through its lawyers on behalf of 208 employees, whose 
rights were violated. The association asked the employer to complete the payment of missing premiums and warned that it would otherwise start legal action. After this, the company agreed to make retrospective payments on condition that the records of the Social Security Institution were wholly verified. During this process, various news items were published in papers and shared in the public domain. It was even discussed in the Turkish parliament. As a result, the company paid the premiums in full, and the process ended in favour of the workers. As regards this subject, a call attack was arranged, and the author participated in the call attack as an observer. The objective of the attack was to make the workers, whose rights had been violated, call the call centre of the Social Security Institution and create a complaint record about the violation of social rights of the workers. However, the interesting point is that the call centre that violated the workers' rights also provides call centre service for the Social Security Institution. In other words, the people who answered the calls within the call attack were informed about the unlawfulness of the company they are working for, and they were at the same time made aware about the Association.

The other issues for which the Association offers advocacy are generally related to individual resistance mechanisms concerning working conditions. For example, a great majority of the call centre employees obtain a health report as a resistance strategy against the frustrating working conditions. This is a type of resistance, which can be qualified as refusing to attend work. In such cases, the purpose is to make the employer fire employees, who can then receive compensation. At this point, what the association does is to inform employees about how to obtain a sickness report and its legal restrictions. If an employee is forced to leave the job in an illegal way, then the Association offers lawyers as support.

One of the interviewees provided the following example of this situation; 
"Getting a sickness report has already become a tactic among workers. For example, a worker got a 30-day absence, but he attended the entertainment activity organised by the company although he was on sickness leave... He eventually got fired. He did this on purpose. He wanted to get his compensation and move on." (Sevda, member)

One of the interviewees takes a sickness report and does not attend work:

"They are trying to exhaust us. And I just get a report and do not go to work. I will get as many reports as possible. They do not leave us any other way out" (Burçak, member)

\section{Raising Collective Consciousness}

In addition to organising and providing advocacy, the Association periodically sends leaks to various websites to influence public opinion and raise collective consciousness among workers. An e-mail sent by a call centre worker is the key to learning the working conditions in that call centre. This is leaked to the public opinion through "GCM leaks". This leak covers a great deal of information including the working hours, pays, frequency of overtime, and length of breaks. According to the Association's declaration about leaks published on its website,

"We are going to leak all data about conditions. We will leak anything...Their pay, working hours, food served, service buses, noise, having a nap in the break room, the hairdresser, the queue in front of toilets, the filter of air conditioning which has not been replaced for five years, and work load, etc. We will leak everything whether good or bad."

The grievances about working conditions in the leaks can be summarized as follows: "We are too busy and the work is exhausting." "The employees are always being monitored and they feel the pressure of this." "Sales expectations are too high." "Toilets are insufficient particularly for women." "Breaks are too short." "The place where we are working is depressing and the air conditioning is bad." "Hundreds of people are working in the same 
place, so contagious illnesses spread quickly." "There is too much noise in the office. We work overtime also at the weekend."

The leaks clearly indicate the informal structure of the association. It is through leaks that an information network among employees occurs and the attention of the employers can be drawn to the uncomfortable working conditions. Such resistance mechanisms are undoubtedly not observed in trade unions.

\section{Reasons for Contacting the Association}

One of the most important issues regarding the organising and sustainability of the aAssociation is whether members contact it for individual or collective reasons. In fact, if a worker contacts the Association for an individual problem, when the problem is solved, that worker may stop interacting. It is certain that one of the prerequisites for the Association's sustainability is organising for collective reasons. Regarding this issue, Ekin's comments are noteworthy:

"Employees have recourse to us for different reasons. We contact the employee who is having trouble in the workplace, but then this employee quits his/her job. This is one of our problems. Our target is to make sure that we keep in touch with the employee as they are working. If we can do this, we will also help the workers cope with the other workplace problems they are likely to encounter while they are working. However, in our case, we are generally in touch with the employees, who are having problems, and when their problems are solved, the communication ends. So, we tell them that even if they have recourse to us for individual reasons, the fight against their individual problems is given with collective efforts. If the person concerned has no energy for it, then we have problems. Above all, people have no perception of organising as workers. We are trying to explain to them something that they have never heard of: What does a worker organisation do?" 
During the interviews, following the question of how the members contacted the Association, they were also asked why they had contacted it. The reason for asking this question was to have a better understanding of their point of view about collective organising. Concerning this issue, a member stated the following:

"I may be able to do nothing alone, but I can raise my voice against the injustice in $x$ company. That's the reason why I am taking part in the actions. I want to do something not only for myself but also for other employees. Here is a platform where I can raise my voice". (Esra, member)

Another member is quite sure about the need for a collective movement:

"We should act collectively no matter whether it is through an association, a trade union or a group completely informal. All we need is to act together. An unorganised power is not power." (Okan, member)

\section{Discussion}

After discussing the case according to the structure, organising practices, collective actions and membership situation of the association, it is clear that there are some differences as well as similarities between other non-union worker organisation forms and the Turkish case. First of all, while worker centres -as a specific example of the communitybased organisations- organise low-wage and immigrant worker groups, the ACCW organises call centre workers in their workplaces. At the same time, the membership structure is uncertain because of the individual dissatisfaction of the workers who contact the Association. As soon as they solve their problem, they could stop interacting with the organisation and participating in the actions, which is a situation that limits the effectiveness and widespread nature of the collective movement. As a similar point, the ACCW provides 
advocacy to workers and raises public awareness of the workplace conditions in call centres like community-based organisations. However, as indicated earlier, the characteristics of the organisations primarily depend on the conditions of the labour market and industrial relations system. Collective actions of the association are not effective enough to attract the attention of the employers and governments compared with the campaigns of worker centres that act simultaneously with the unions.

Although call centres are suitable workplaces for collective organising (YücesanÖzdemir, 2014) in relation to long working hours, insecure and flexible working conditions, monotonous, repetitive, and stressful work; collective actions against these conditions and unions are the exception. This is mostly because of the reasons that were explained as traditional union ineffectiveness and decline in the Turkish case. Work organisation and highly intense control mechanisms in call centres are additional factors making unionisation difficult. Such factors as the individualized character of the work and short breaks make it highly difficult for workers to come together to share their grievances. Flexible working hours and different work shifts prevent workers from raising collective awareness. Workers at risk of losing their jobs feel insecure about trade unions and other collective movements. All these factors and other innate features of this job are characterized as organisational barriers against unionisation (Bain et al., 2004) like in any other country. However, one of the main obstacles to organising or to acting collectively in Turkish call centres is the fear of losing the job.

The high labour turnover, which is commonly observed in Turkey is another important barrier against unionisation (Yücesan-Özdemir, 2012: 36). Furthermore, recent years witnessed dismissal of some call centre workers who were trade union members. At this 
point, it is possible to claim that there is a fear factor affecting call centre workers' trade union membership.

These call centre workers are quite young, and their lack of class-consciousness also has an impact on collective organising dynamics. Instead of claiming their rights traditionally and collectively, call centre workers generally find individual and temporary ways of coping with thestressful characteristics of working conditions, their inadequate knowledge about their rights and a lack of collective organisation to obtain support in case of a violation of rights. This clearly indicate that there is a representation gap in call centres. In this point, the ACCW plays an alternative role for advising, organising and representing call centre workers' interests. Although it is controversial whether it has the potential to organise and mobilise a large group of call centre workers for the long term, this organising attempt is important for building a movement for workers who are dismissed from collective actions. The process is also part of a wider struggle to build collective movements in Turkey.

Nevertheless, conditions have recently changed regarding the legal barriers for union organising of call centre workers, and after the introduction of new Trade Union Law in Turkey in 2012 branches of work were re-defined, and there was no longer a barrier to call centre workers organising under the umbrella of a union within the scope of the communication branch of work. Following this legal change, the 'Progressive Communication and Call Centre Workers' Union' was founded in May 2013, which is mainly managed by the founders of the Association. The Law amendment mentioned above enabled the foundation of the Union, and becoming a union member became easier through "e-membership". However, "emembership" did not ensure the expected number of members. In fact, the deficiencies in the system made it difficult for call centre workers to become trade union members. 
Following the enactment of the Trade Union Law, several problems have been experienced in the new industrial relations system about identifying branches of work and workplaces affiliated with the sector. This causes a difficulty in determining workplaces operating as call centres, thereby making it difficult for the trade union to organise workers. The impression acquired from the recent informal meetings with the founders of the Union is that although the Union has increased the number of its members, it is rather difficult for them to exceed the collective bargaining threshold mentioned before. Additionally, the Union lacks professional staff to manage the process at this stage.

The Progressive Communication and Call Centre Workers Union is quite a new organisation and its effectiveness is controversial. It is too early to extensively speculate about the prospects of the union. Therefore, it is possible to claim that the existence of an informal organisation is still functional. However, organising workers -even if informally- is not easy due to the innate characteristics of the job. Returning to the earlier discussion about these new forms and 'pre' or 'proto' unions relations, in the current case two forms of organisations exist at the same time. Therefore, the Association does not have a role as a proto-union, because it is still in operation after the establishment of the union. In other words the two organisations have different roles in the Turkish context.

According to a recent interview with the founders in a journal, theyFounders of the association admit that the organisational capacity of the association is wider than the trade union in these circumstances. They are planning to conduct organisational activities in the service and banking sector by way of the Association and in the communication sector through the trade union. Additionally they indicate the aim of the trade union is to overcome the threshold and to make collective bargaining effective. 
There is no doubt that a trade union in its founding phase may encounter such problems. The existence of a new trade union should be undoubtedly regarded as an important development. However, when the general organising problems trade unions have experienced in Turkish industrial relations system are considered, we will see whether the Call Centre Workers' Union will be able to maintain effective and efficient unionism over time.

\section{Conclusion}

This paper has aimed to draw attention to a non-union worker organisation as an example of a new type of actor in industrial relations in a developing country. These types of actors have appeared after the decline of the traditional unions, and they became a subject of academic discussions about effective representation of the workers who are excluded from the formal mechanisms. The study analysed the effectiveness of the case organisation Association of Call Centre Workers- and the relationships between the informal and formal worker organisations in the process of establishing a new trade union for call centre workers.

As the literature about the new actors in industrial relations indicates, the discussions are mostly regarding the situation and structure of these actors in contrast to the trade union movement. Are they going to be a substitute or complement to the unions, or can the two types of institutions form mutually beneficial coalitions (Heery and Frege, 2006)? This study focuses on an example with a tendency for the two forms being able to work together, and each movement being effective in its own right. According to the research results, the trade union, which tries to organise call centre workers, struggles to become a formal representation channel for unrepresented workers in Turkey. On the contrary, the ACCW is successful in producing mobilisation for collective action although there are some problems with keeping the members who experienced problems in the workplace. The Association has 
visible acquisitions to establish voice mechanisms for call centre workers and to represent their interests.

Furthermore, for a sustainable movement of a new types of worker, it is essential to establish a cooperation between both formal and informal worker organisations -a hybrid structure- particularly in developing countries where it is possible to observe some gaps and problems in their industrial relations system. Although hybridity is mostly seen in advanced economies, the mentioned cooperation is also functional in developing countries. The employment relationship has a nonstandard structure in these countries so alternative organisations have the capability to organise vulnerable workers with established unions. From this perspective, this paper contributes to empirical knowledge about informal organising and its potential for filling the representation gap in a developing country.

It is obvious that different labour movement traditions and union structures shape different mobilisation practices against unregulated labour market conditions. When the traditional representation channels do not exist for workers (Tapia et al. 2014), they may need alternative ways for winning their rights and expressing their voices. However, every labour movement should be assessed in its own specific conditions. The Association's collective actions and representation strategies might not be effective like the successful campaigns and the actions of worker centres formed with the support of trade unions in the USA. The existing trade union for call centre workers in Turkey might not constitute a strong support for the workers yet, but by having different roles than those of the Association they have the potential to represent and mobilise them in the limited conditions of labour movements. Further studies should also analyse the effectiveness of informal and alternative worker organisations in the example of various existing organisations, such as an association of 
construction workers or of domestic workers, for filling the organising gap for unorganised worker groups in Turkey.

\section{References}

Ackers, P., C. Smith and P. Smith (1996), 'Against All Odds? British Trade Unions in the New Workplace', in P. Ackers, C. Smith and P. Smith (eds.), The New Workplace and Trade Unionism, London: Routledge, pp. 1-41.

Bain, P., P. Taylor, K. Gilbert and G. Gall (2004), 'Failing to Organise- or Organising to Fail? Challenge, Opportunity and the Limitations of Union Policy in Four Call Centres', in G. Healy, E. Heery, P. Taylor and W. Brown (eds.), The Future of Worker Representation, Basingstoke: Palgrave, pp. 62-81.

Bryson, A. and R.B. Freeman (2013), 'Employee Perceptions of Working Conditions and The Desire for Worker Representation in Britain and the US', Journal of Labor Research, 34, 1, 129.

Cox, A. (2015), 'The Pressure of Wildcat Strikes on the Transformation of Industrial Relations in a Developing Country: The Case of Garment and Textile Industry in Vietnam', Journal of Industrial Relations, 57, 2, 217-290.

Edwards, P.K. (1990), 'Understanding Conflict in the Labour Process: The Logic and Autonomy of Struggle', in D. Knights and H. Willmott (eds.), Labour Process Theory, London: Macmillan, pp. $125-153$.

Findlay, P. and C. Warhurst (2011), 'Union Learning Funds and Trade Union Revitalization: A New Tool in the Toolkit', British Journal of Industrial Relations, 49, s1, 115-134. 
Fine, J. (2005a), 'Community Unions and the Revival of the American Labor Movement', Politics\&Society, 33, 1, 153-199.

Fine, J. (2005b), 'Worker Centres: Organizing Communities At the Edge of the Dream', Retrieved from http://heinonline.org.

Fine, J., J. Grabelsky and V. Narro (2008), 'Building a Future Together: Worker Centres and Construction Unions', Labor Studies Journal, 33, 1, 27-47.

Freeman R.B., P. Boxall and P. Haynes (2007), What Workers Say-Employee Voice in the AngloAmerican Workplace, New York: Cornell.

Givan, R.K. (2007), 'Side by Side We Battle Onward? Representing Workers in Contemporary America', British Journal of Industrial Relations, 45, 4, 829-855.

Heckscher, C. and F. Carre (2006), 'Strength in Networks: Employment Rights Organisations and the Problem of Co-Ordination', British Journal of Industrial Relations, 44, 4, 605-628.

Heery, E., G. Healy and P. Taylor (2004) 'Representation at Work: Themes and Issues', in G. Healy, E. Heery, P. Taylor and W. Brown (eds.), The Future of Worker Representation, Basingstoke: Palgrave, pp.1-36.

Heery, E. and L. Adler (2004), 'Organizing the Unorganized', in C. Frege and J. Kelly (eds.), Varieties of Unionism: Strategies for Union Revitalisation in a Globalizing Economy, New York: Oxford University, pp.45-69.

Heery, E. and C. Frege (2006), 'New Actors in Industrial Relations', British Journal of Industrial Relations, 44, 4, 601-604.

Heery, E. (2010), 'Worker Representation in a Multiform System: A Framework for Evaluation', Journal of Industrial Relations, 52, 5, 543-559.

Hyman, R. (1997), 'Trade Unions and Interest Representation in the Context of Globalization', Transfer, 3, 515-533. 
Hyman, R. (2015), 'Three Scenarios for Industrial Relations in Europe', International Labour Review, 154, 1, 5-14.

Jenkins, J. (2013), 'Organizing 'Spaces of Hope': Union Formation by Indian Garment Workers', British Journal of Industrial Relations, 51, 3, 623-643.

Michelson, G., S. Jamieson and J. Burgess (2009), 'Filling the Void: Emerging Actors in Australian Industrial Relations', Journal of Economic and Social Policy, 13, 1, 1-19.

Osterman, P. (2006), 'Community Organizing and Employee Representation', British Journal of Industrial Relations, 44, 4, 629-649.

Sen, R. and C.H. Lee (2015) 'Workers and Social Movements of the Developing World: Time to Rethink the Scope of Industrial Relations?', International Labour Review, 154, 1, 37-45.

Sullivan, R. (2010), 'Organizing Workers in the Space Between Unions: Union-Centric Labor Revitalisation and the Role of Community-Based Organisations', Critical Sociology, 36, 6, 793819.

Suzuki, A. (2008), 'Community Unions in Japan: Similarities and Differences of Region-Based Labour Movements between Japan and Other Industrialized Countries', Economic and Industrial Democracy, 29, 4, 495-520.

Tapia, M. (2013), 'Marching to Different Tunes: Commitment and Culture as Mobilizing Mechanisms of Trade Unions and Community Organisations', British Journal of Industrial Relations, 51,4, 666-688.

Tapia, M. and L. Turner (2013), 'Union Campaigns as Countermovements: Mobilising Immigrant Workers in France and The United Kingdom', British Journal of Industrial Relations, $51,3,601-622$.

Tapia, M., Turner, L. and R.S. (2014), 'Union Campaigns as Countermovements- 'Best Practice' Cases from the United Kingdom, France and the United States', in L.H. Adler, M. Tapia and L. 
Turner (eds.), MobilisingAgainst Inequality- Unions, Immigrant Workers andthe Crisis of Capitalism, New York: Cornell University, pp.14-35.

Tokol, A. (2012), Türk Endüstri Illişkileri Sistemi, Bursa: Dora.

Webster E. (2015), 'The Shifting Boundaries of Industrial Relations: Insights from South Africa', International Labour Review, 154, 1, 27-36.

Yücesan-Özdemir, G. (2012), 'Anadolu'da Çağrı Merkezi Çalışanları ve Sendikal Örgütlenme', Türk-iss, 396, 35-38.

Yücesan-Özdemir, G. (2014), Inatçı Köstebek: Çağrı Merkezlerinde Gençlik, Sınıf ve Direniş, İstanbul: Yordam. 